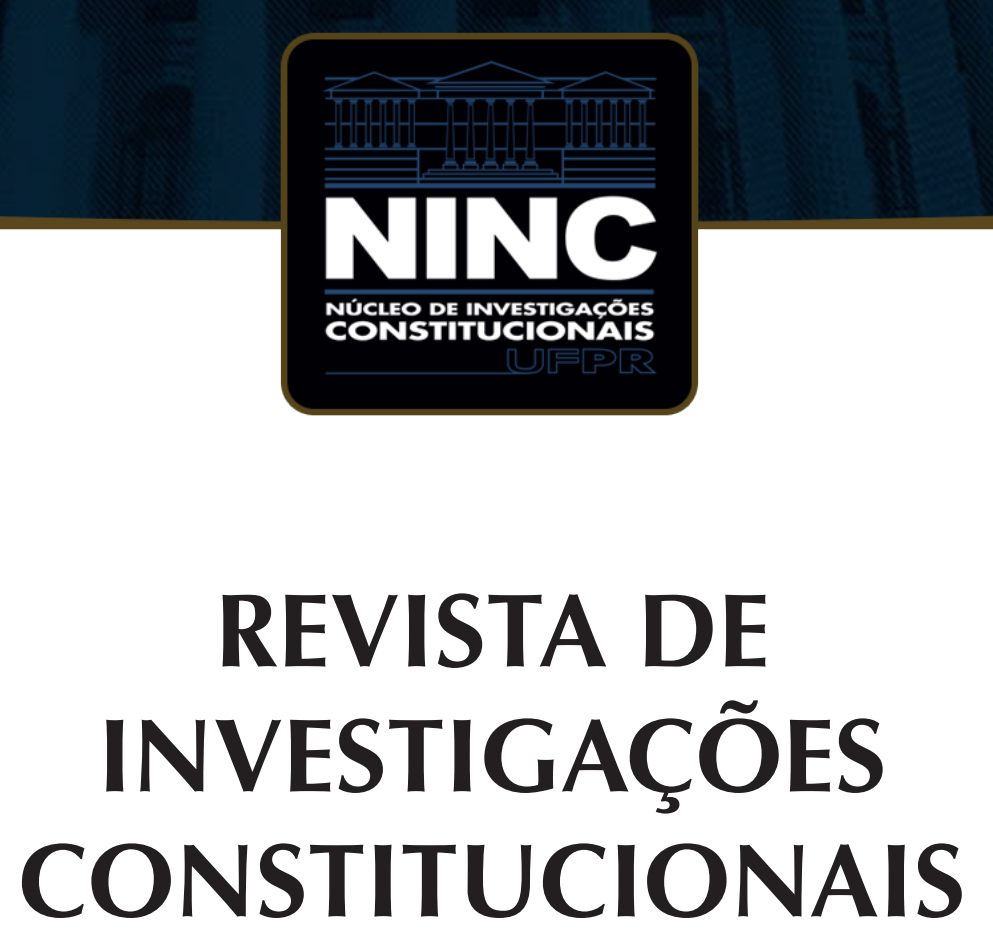

JOURNAL OF CONSTITUTIONAL RESEARCH

vol. 5 | n. 1 | janeiro/abril 2018 | ISSN 2359-5639 | Periodicidade quadrimestral Curitiba | Núcleo de Investigações Constitucionais da UFPR | www.ninc.com.br 


\section{Autocontenção à brasileira? Uma taxonomia dos argumentos jurídicos (e estratégias políticas?) explicativo(a)s do comportamento do STF nas relações com os poderes majoritários}

\section{A Brazilian self-restraint? A taxonomy of legal arguments (and political strategies?) which explain the behavior of the Supreme Court in relations with the major branches of power}

FLÁVIA DANIELLE SANTIAGO LIMA*

Universidade de Pernambuco (Brasil) Universidade Federal de Pernambuco (Brasil)

flavia-santiago@uol.com.br

\section{JOSÉ MÁRIO WANDERLEY GOMES NETO**}

Universidade Católica de Pernambuco (Brasil) Centro Universitário CESMAC (Brasil) josemwgomes@gmail.com

Recebido/Received: 24.10.2017 / October 10th, 2017 Aprovado/Approved: 31.12.2017 / December 31st, 2017

Resumo

Como as cortes justificam sua opção pela autocontenção, isto é, sua escolha expressa ou implícita por não decidir um caso, notadamente na presença de repercussões políticas, favorecendo as instituições majoritárias e preservando os órgãos julgadores de custos políticos indesejáveis? A literatura brasileira sobre a revisão judicial, em Direito e em Ciência Política, debruça-se sobre as noções de ativismo e de autocontenção, estabelecendo seus pressupostos
Abstract

How do the courts justify their choice for self-restraint, case, notably in the presence of political repercussions, favoring the majority institutions and preserving the judges of undesirable political costs? The Brazilian literature on judicial review, in Law and Political Science, focuses on the notions of activism and self-restraint, establishing its theoretical assumptions and analyzing the data that show the that is, their express or implied choice for not deciding a

Como citar esse artigo/How to cite this article: LIMA, Flávia Danielle Santiago; GOMES NETO, José Mário Wanderley. Autocontenção à brasileira? Uma taxonomia dos argumentos jurídicos (e estratégias políticas?) explicativo(a)s do comportamento do STF nas relações com os poderes majoritários. Revista de Investigações Constitucionais, Curitiba, vol. 5, n. 1, p. 221-247, jan./abr. 2018. DOI: $10.5380 /$ rinc.v5i1.55990.

* Professora da Universidade de Pernambuco e do Programa de Pós-Graduação da Universidade Federal de Pernambuco - PPGD-UFPE (Recife, PE, Brasil). Doutora em Direito pela UFPE. Advogada da União. E-mail: flavia-santiago@uol.com.br.

** Professor da Graduação e Pós-Graduação da Universidade Católica de Pernambuco e do Centro Universitário CESMAC (Recife, PE, Brasil). Doutor em Ciência Política pela UFPE (Recife, PE, Brasil). Advogado e Cientista Político. E-mail: josemwgomes@gmail. com. 
teóricos e analisando os dados que mostram a prática decisória (e omissões) do STF. Inexiste, contudo, um inventário sobre os critérios técnicos utilizados pelo tribunal. Este artigo inova ao oferecer esta leitura: como o STF pode se eximir de julgar? Há argumentos jurídico-processuais que viabilizam esta opção institucional, empregados em sede de controle concentrado e difuso de constitucionalidade por aquele Tribunal. Oferece-se ao leitor, através de uma metodologia exploratória e descritiva do conteúdo das decisões (de natureza autocontida) tomadas pelos membros do Supremo Tribunal Federal, um texto que pretende organizar e categorizar as diversas formas pelas quais o fenômeno institucional da autorrestrição judicial se manifesta na esfera do controle de constitucionalidade.

Palavras-chave: controle de constitucionalidade; judicialização; Supremo Tribunal Federal; autocontenção; taxonomia dos argumentos jurídicos. decision-making practice (and omissions) of the STF. There is, however, no inventory on the technical criteria used by the court. This article innovates by offering this reading: how can the STF exempt itself from judging? There are legal-procedural arguments that make this institutional option feasible, employed in a concentrated and diffuse judicial review by that Court. The reader is offered, through an exploratory and descriptive methodology of the content of decisions (of a self-contained nature) taken by members of the Federal Supreme Court, a text that intends to organize and categorize the various ways in which the institutional phenomenon of judicial self-restraint is manifested in the sphere of judicial review.

Keywords: judicial review; judicialization; Brazilian Supreme Court; self-restraint; taxonomy of legal arguments.

\section{SUMÁRIO}

1. Introdução. 2. Do não exercício do poder institucional: a autocontenção como elemento da jurisdição constitucional. 3. Autorrestrição material expressa: respeito às decisões majoritárias e à função típica dos poderes estatais; 3.1. Estabelecendo os contornos de sua intervenção: a doutrina das questões políticas; 3.2. É possível substituir a vontade do parlamento? O papel do legislador negativo kelseniano; 3.3. Respeitando a separação dos poderes: atos interna corporis do Legislativo e "reserva da Administração". 4. Autorrestrição formal expressa (ou virtudes passivas)? llegitimidade ativa, pertinência temática, competência e requisito de subsidiariedade no STF; 4.1. Restringindo o acesso à jurisdição constitucional: a ilegitimidade ativa e o "filtro" da pertinência temática em sede de ação direta; 4.2. (Re)definindo sua própria jurisdição: competência originária e o requisito da subsidiariedade para arguição de descumprimento de preceito fundamental; 5. Autorrestrição "tácita": o silêncio como resposta da corte (aguardando julgamento, perda de objeto (bloco de constitucionalidade/emenda), alteração legislativa e ilegitimidade superveniente). 6. Conclusões: Autorrestrição judicial como expressão de comportamento estratégico deliberado do STF; 7. Referências.

\section{INTRODUÇÃO}

Como as cortes justificam sua opção pela autocontenção, isto é, sua escolha expressa ou implícita por não decidir um caso, notadamente na presença de repercussões políticas, favorecendo as instituições majoritárias e preservando os órgãos julgadores de custos políticos indesejáveis?

Desde sua obra seminal sobre a intervenção judicial em litígios envolvendo políticas públicas, Robert Dahl1 já alertava sobre as dificuldades enfrentadas pelas instituições judiciárias para decidir contramajoritariamente, ressaltando o caráter estratégico

1 DAHL, Robert A. Decision-making in a democracy: The Supreme Court as a national policy-maker. Journal of Public Law, London, v. 6, 1957. 
das decisões e a existência de uma série de fatores que contribuíam contrariamente ao exercício da revisão judicial e favoravelmente aos interesses políticos majoritários.

No referido trabalho, a Suprema Corte estadunidense somente lograria o objetivo de impedir mudanças no panorama político caso cumprisse a condição de manter consistência com os valores adotados por aqueles que representassem a maioria legislativa, num dado momento da história e da política2.

Diversos modelos formais apresentados pela literatura da Judicial Politics, oferecem hipóteses e premissas explicativas do comportamento judicial, seja este ativo ou omissivo, seja ativista ou autocontido. Para o modelo estratégico, as instituições jurídicas importam e podem influenciar no comportamento dos atores judiciais, mas não sozinhas, sendo um dos conjuntos possíveis de variáveis numa vasta rede de incentivos.

Na lógica do referido modelo, os juízes adotam estratégias para chegar aos seus objetivos, uma vez que considera a existência de várias restrições externas ao seu comportamento, pois levam em consideração a reação de todos os agentes no processo jurídico-político, seja no âmbito interno ou externo dos tribunais, bem como as consequências futuras de suas decisões em outros campos, a exemplo do equilíbrio democrático e da economia ${ }^{3}$. Neste sentido, as cortes têm o desafio de acomodar os entraves externos para manter sua integridade institucional. Ao antecipar que eventuais confrontos podem resultar em perda (ou relativização) da independência judicial, sua tendência seria evitar o confronto com outros ramos de poder 4 .

A pesquisa parte da hipótese de que, além de serem fatores que influenciam no comportamento, os argumentos jurídicos também ajudam a corte em sua estratégia, oferecendo os instrumentos legais necessários a viabilizar a conduta escolhida, seja ativista ou autocontida, bem como justificativas técnico-formais para suas escolhas, que reduzem os custos de suas decisões perante os demais agentes políticos, as outras instituições estatais e/ou a opinião pública. No Brasil, este cálculo é mais claro e mais viável no ambiente do Supremo Tribunal Federal (STF), uma vez que se trata do foro responsável por julgar as grandes causas nacionais, bem como em razão de seu desenho institucional concentrador das decisões acerca dos conflitos de relevância política e jurídica.

Neste quadro, a literatura brasileira sobre a revisão judicial, em Direito e em Ciência Política, debruça-se sobre as noções de ativismo e de autocontenção, estabelecendo seus pressupostos teóricos e analisando os dados que mostram a prática decisória (e omissões) do STF. Inexiste, contudo, um inventário sobre os critérios técnicos utilizados pelo tribunal. Este artigo inova ao oferecer esta leitura: como o STF pode se

\footnotetext{
2 DAHL, Robert A. Decision-making in a democracy: The Supreme Court as a national policy-maker. Journal of Public Law, London, v. 6, 1957. p. 294.

3 POSNER, Richard A. How judges think. Cambridge, Harvard University Press, 2010.

4 WHITTINGTON, Keith E.. Legislative sanctions and the strategic environment of judicial review. International Journal of Constitutional Law, v. 1, n. 3, p. 446-474, jul. 2003, p. 446-447.
} 
eximir de julgar? Há argumentos jurídico-processuais que viabilizam esta opção institucional, empregados em sede de controle concentrado e difuso de constitucionalidade por aquele Tribunal.

Oferece-se ao leitor, através de uma metodologia exploratória e descritiva do conteúdo das decisões (de natureza autocontida) tomadas pelos membros do Supremo Tribunal Federal, um texto que pretende organizar e categorizar as diversas formas pelas quais o fenômeno institucional da autorrestrição judicial se manifesta na esfera do controle de constitucionalidade.

\section{DO NÃO EXERCÍCIO DO PODER INSTITUCIONAL: A AUTOCON- TENÇÃO COMO ELEMENTO DA JURISDIÇÃO CONSTITUCIONAL}

A autocontenção é contemporânea ao estabelecimento da própria revisão judicial, eis que foi aventada no célebre Marbury x Madison (1803), em que o Justice Marshall, embora tenha afirmado a supremacia da constituição e a atribuição da Suprema Corte em resguardá-la, entendeu que, no mérito, não caberia ao tribunal interferir em temas afetos a outros poderes. Sua decisão foi norteada por uma inegável contenção, em virtude da negativa da ordem pleiteada.

O respeito às decisões majoritárias e à separação entre os poderes paira sobre o exercício da jurisdição constitucional desde os seus primórdios. Acima do jogo institucional, uma relevante questão teórico-filosófica: a compatibilização da revisão judicial com o ideal democrático.

Inicialmente, a concepção de autorrestrição (ou autocontenção) judicial não traduzia ou estabelecia um modelo específico de democracia, como se mostrou no trabalho de James Thayer 5 . Posteriormente, as teorizações se tornaram mais complexas - com a consequente conformação ou definição de uma função para o judicial review, que se vislumbra na produção de Alexander Bickel6, com esteio no princípio majoritário, compreendendo a corte em papéis que vão além de suas atividades primárias. Em John Hart Ely7, tem-se a função jurisdicional mais próxima de uma definição mais clara de uma democracia procedimental, na qual o Judiciário seria uma instituição afiançadora de suas condições. Cass Sunsteinn, por sua vez, na formulação de um modelo deliberativo democrático, tenta conformar metodologicamente a atuação da corte, que deve afastar-se de temas controversos.

Limitação pela democracia - em várias de suas versões - aceitação de limites cognitivos e estruturais à intervenção judicial e, por fim, a transformação destas

\footnotetext{
5 POSNER, Richard A. The rise and fall of judicial self-restraint. California Law Review, Berkeley, vol. 100, n. 3, p. 519-556, 2012. 6 BICKEL, Alexander M. The least dangerous branch: the Supreme Court at the bar of politics. Indianapolis: Bobbs-Merrill, 1962 7 ELY, John Hart. Democracy and distrust: A theory of judicial review. Harvard University Press, 1980. 8 SUNSTEIN, Cass R. Designing democracy: What constitutions do. Oxford University Press, 2001.
} 
preocupações em diretrizes ou parâmetros interpretativos a serem seguidos pelas cortes são os elementos definidores das perspectivas de conformação judicial, em relação à racionalidade inerente à decisão de apreciar, ou não, o conflito submetido ao órgão judicial9.

Assim, o problema democrático paira sobre o debate do exercício da revisão judicial: surgem, então, desde as obras de autores que propunham a deferência ou presunção de constitucionalidade (James B. Thayer) a outros que preferiam ver na Suprema Corte a fundamentação de suas decisões apartadas de considerações não jurídicas, de modo que estas fossem "conformes" a determinada concepção de sua atuação (Herbert Wechsler) ou, ainda, como Alexander Bickel, que tentavam visualizar, em resposta às credenciais contramajoritárias, um papel relevante para a corte como um foro de debates principiológicos, reconstruindo a perspectiva de autocontenção.

Os conceitos de ativismo e de autocontenção lidam diretamente com o que pode ser a pergunta principal a ser questionada sobre [uma corte suprema] - qual o seu papel fundamental e qual o alcance dos poderes da corte em nosso sistema de governo?10

Teorizando sobre tal questão comportamental dos órgãos judiciais, tem-se a construção de um papel restrito para as cortes, pelos mais diversos meios: (a) reconhecimento de uma presunção de constitucionalidade dos atos dos demais poderes; (b) coerência na interpretação dos dispositivos constitucionais; (c) demarcação da atuação da corte a determinados temas, em que sua atuação seria indispensável e, hodiernamente. (d) redução do âmbito da decisão, naquilo outrora denominado de uma "via hermenêutica" da autocontenção ${ }^{11}$.

Em meio a estas diversas concepções dos papéis dos órgãos judiciais no exercício da revisão judicial, concentrada ou difusa, a autolimitação judicial reconhece a necessidade de inserção da corte num ambiente predominantemente político - às voltas com diversas variáveis estratégicas que condicionam a atividade jurisdicional: desde a necessidade de aceitabilidade de suas decisões às dificuldades - inclusive técnicas - que enfrenta para o exercício de sua atividade.

\footnotetext{
9 LIMA, Flávia Danielle Santiago. Jurisdição constitucional e política: ativismo e autocontenção no STF. Curitiba: Juruá, 2014. 10 HALPERN, Stephen C.; LAMB, Charles M. Historical perspectives. In: HALPERN, Stephen C.; LAMB, Charles M (ed.). Supreme Court activism and restraint. Lexington, Lexington Books, 1982, p.1.

11 LIMA, Flávia Danielle Santiago. Jurisdição constitucional e política: ativismo e autocontenção no STF. Curitiba: Juruá, 2014.
} 


\section{AUTORRESTRIÇÃO MATERIAL EXPRESSA: RESPEITO ÀS DECI- SÕES MAJORITÁRIAS E À FUNÇÃO TÍPICA DOS PODERES ESTA- TAIS}

Para Alexander Bickel, a doutrina constitucional e o próprio tribunal se olvidam do tríplice poder que este último possui, considerando que seu espectro de possibilidades não se limita apenas às opções de manutenção ou anulação de uma norma diante de sua incompatibilidade com os princípios. A corte conta, ainda, com a opção de nada fazer, o que torna viável a manutenção da "tensão entre o princípio e a oportunidade", sem o comprometimento daquele ${ }^{12}$.

Não se questiona a existência ou a validade da revisão judicial; não há uma negativa apriorística das potencialidades da corte na salvaguarda de importantes fundamentos do Estado de Direito: há, todavia, a compreensão que as instituições judiciais devem ser inseridas dentre os demais entes estatais, dotados de competências específicas, havendo uma dinâmica permanente de distribuição das competências institucionais de cada ramo de poder.

Esta aparente opção pelo não julgamento pode espelhar a consciência que a corte possui sobre as suas limitações institucionais. Ao abordar, p.ex., a doutrina das questões políticas, Bickel lembra que esta construção é amparada no senso de "falta de capacidade", consistente em diversos fatores que, no conjunto, representam a vulnerabilidade interna de uma instituição que, numa "democracia madura", é eleitoralmente irresponsável e não tem força para impor suas decisões ${ }^{13}$.

\subsection{Estabelecendo os contornos de sua intervenção: a doutrina das questões políticas}

A Lei n. 9.996/2000 concede anistia a todos os considerados faltosos para com a Justiça Eleitoral, vale dizer, candidatos eleitos, ou não, tanto para cargos no Legislativo, como no Executivo, além de mesários e eleitores ausentes nas eleições de 1996 e 1998. Ao editá-la, o Congresso Nacional utilizou-se da sua competência assegurada (Constituição Federal, art.48, VIII). O Parlamento detém, inegavelmente, a competência para conceder anistia, inclusive a seus próprios membros. Restringir esta competência, quando o próprio texto maior não o fez, descabe ao intérprete. Não é possível coibir, pela via da intervenção judiciária, que se aprovem normas que também incidam, ou venham a incidir em benefício dos cidadãos que, momentaneamente, estejam exercendo mandatos

${ }_{12}$ BICKEL, Alexander M. The least dangerous branch: the Supreme Court at the bar of politics. Indianapolis: Bobbs-Merrill, 1962, p. 69.

${ }_{13}$ BICKEL, Alexander M. The least dangerous branch: the Supreme Court at the bar of politics. Indianapolis: Bobbs-Merrill, 1962, p. 184. 
parlamentares. A tanto corresponderia verdadeira cassação judiciária da atribuição legislativa.

Min. Ellen Gracie, ADI 2306, 2002 (Destaque nosso).

Embora tenha sido exposta a já em Marbury x Madison (1803), ao longo dos anos e nos mais diversos ordenamentos é possível identificar múltiplas noções sob a denominação de teoria das questões políticas. Para Mark Tushnet, a doutrina abrange a decisão acerca da possibilidade de que um determinado ramo político interprete a constituição ("does the Constitution give a political branch the final power to interpret the Constitution?") 14. Outros defendem uma versão substancial ("meaningful political question doctrine"), que compreende que seu texto atribui aos poderes Executivo e Legislativo a autoridade final para fixar o significado de algumas previsões constitucionais 15.

No Brasil, a doutrina das questões políticas é invocada pelo STF desde o célebre $\mathrm{HC} \mathrm{n}^{\circ} 300$, impetrado por Rui Barbosa, em favor de presos políticos durante a Presidência de Floriano Peixoto, quando o Tribunal afirmou não poder interferir na seara discricionária do Chefe do Executivo ${ }^{16}$. Após extensivo uso no período entre 1910-193017 em questões relativas às decisões do executivo, mais recentemente a opção pela não sindicabilidade judicial recai sobre temas relativos às dinâmicas decisórias do Congresso Nacional, como se verá mais adiante.

A própria Suprema Corte dos EUA, numa decisão de 1962 (Baker v. Carr), procedeu à sistematização dos critérios para sua aplicação ${ }^{18}$, alvo de profunda crítica teórica ${ }^{19}$ e que não parece ter servido como um efetivo critério de restrição para sua atuação.

\footnotetext{
14 TUSHNET, Mark. Law and prudence in the law of justiciability: the transformation and disappearance of the political question doctrine. North Carolina Law Review, Chapel Hill, v. 80, p. 1203-1235, 2002. p. 1207.

15 HENKIN, Louis. Is there a "political question" doctrine? The Yale Law Journal, New Heaven, v. 85, n. 5, p. 597-625, apr. 1976. p. 599.

16 SOUZA JÚNIOR, Antônio Humberto. O Supremo Tribunal Federal e as questões políticas. Porto Alegre: Síntese, 2004.

17 A extensiva pesquisa de Teixeira mostra que a doutrina foi utilizada para eximir o tribunal de decidir relevantes questões políticas da época, como decretação de estados de sítio e intervenções federais, duplicata de governos e assembleias estaduais, processo de impeachment de governante estadual e banimento da família imperial. TEIXEIRA, José Elares Marques. A doutrina das questões políticas no Supremo Tribunal Federal. Porto Alegre: Sergio Antonio Fabris Editor, 2005.

18 "1. "Textually demonstrable constitutional commitment of the issue to a coordinate political department;" as an example of this, Brennan cited issues of foreign affairs and executive war powers, arguing that cases involving such matters would be "political questions"; 2. "A lack of judicially discoverable and manageable standards for resolving it;"; 3. "The impossibility of deciding without an initial policy determination of a kind clearly for nonjudicial discretion;"; 4. "The impossibility of a court's undertaking independent resolution without expressing lack of the respect due coordinate branches of government;"; 5. "An unusual need for unquestioning adherence to a political decision already made;" 6 . "The potentiality of embarrassment from multifarious pronouncements by various departments on one question." CHOPER, Jesse H. The political question doctrine: suggested criteria. Duke Law Journal, Durham, v. 54, p. 1457-1523, 2005. p. 1458-9.

19 TUSHNET, Mark. Law and prudence in the law of justiciability: the transformation and disappearance of the political question doctrine. North Carolina Law Review, Chapel Hill, v. 80, p. 1203-1235, 2002. p. 1207.
} 
A partir dos anos 1970, cogita-se o descrédito da teoria das questões políticas nos Estados Unidos. Em clássico artigo de 1976, Louis Henkin afirmava que a doutrina não desempenhava um papel relevante na jurisprudência da Corte, constituindo tão somente um conjunto de princípios óbvios de interpretação, como a necessidade de que os tribunais aceitem as decisões dos poderes políticos em suas respectivas áreas ou a impossibilidade de estabelecimento de limites à atividade destes quando não expressos na constituição20. A decisão do Tribunal em Bush v. Gore - contenda tipicamente política - teria enfraquecido ainda mais a teorização21.

Uma máxima final que merece atenção é aquela que estipula que a corte não responderá a questões políticas, sendo estas resolvidas de modo mais apropriado pelos Poderes Executivo e Legislativo. O problema com esta máxima é que os juízes, de tempos em tempos, têm discordado sobre o que vem a constituir uma questão política. Neste sentido, "a definição de uma questão política pode ser expandida ou contraída, à maneira de um acordeon, para atender às exigências dos tempos"22.

Nesse contexto, a political question doctrine é um engenhoso instrumento, pois o estabelecimento de critérios prévios e sua aplicação acabam por ratificar a autoridade judicial. Isto porque uma de suas interpretações se refere ao afastamento da demanda, mas também pela possibilidade de que o próprio Judiciário tenha a prerrogativa de determinar a quem pertence o poder decisório sobre um dado tema 23 .

\section{2. É possível substituir a vontade do parlamento? 0 papel do legis- lador negativo kelseniano}

Seria desejável, numa perspectiva equilibrada de diálogos institucionais, uma constante criação judicial do Direito em nosso ordenamento jurídico? A resposta do STF à tal indagação tem sido fluida ao longo dos tempos, ora repelindo a possibilidade

\footnotetext{
20 "That "[t]he courts are bound to accept decisions by the political branches within their constitutional authority," "[t]he courts will not find limitations or prohibitions on the powers of the political branches where the Constitution does not prescribe any." HENKIN, Louis. Is there a "political question" doctrine? The Yale Law Journal, New Heaven, v. 85, n. 5, p. 597-625, apr. 1976. p. 599.

${ }^{21}$ Essa constatação, todavia, é lamentada por Rachel Barkow, pois o emprego da noção poderia fortalecer a corte para a solução de questões constitucionais. BARKOW, R. More Supreme than court? The fall of the political question doctrine and the rise of judicial supremacy. Columbia Law Review, New York, v. 102, n. 2, mar. 2002. p. 237-336. Em sentido diverso, há quem defenda sua centralidade para a adjudicação constitucional, pois é utilizada como critério para as decisões do tribunal, ainda que de forma não expressa ("the secret political question doctrine"). SEIDMAN, Louis Michael. The secret life of the political question doctrine. John Marshall Law Review, v. 37, p. 441-480, 2004, p. 442-445.

22 LAMB, Charles M. Judicial Restraint on the Supreme Court. In: HALPERN, Stephen C.; LAMB, Charles M (ed.). Supreme Court Activism and Restraint. Lexington, LexingtonBooks, 1982, p.21.

23 CHOPER, Jesse H. The political question doctrine: suggested criteria. Duke Law Journal, Durham, v. 54, p. 1457-1523, 2005. p. 1462.
} 
em autocontenção expressa, ora abrindo exceções a esta barreira substancial e permitindo, em caráter ativista, verdadeira oportunidade para ir além da decisão do conflito, desde a regulamentação de questões à produção normativa original.

Na decisão sobre a "cláusula de barreira", o Min. Relator Marco Aurélio Mello anunciou que

(...) é possível antever que o Supremo Tribunal Federal acabe por se livrar do vetusto dogma do legislador negativo e se alie à mais progressiva linha jurisprudencial das decisões interpretativas com eficácia aditiva, já adotadas pelas principais Cortes Constitucionais européias. A assunção de uma atuação criativa pelo tribunal poderá ser determinante para a solução de antigos problemas relacionados à inconstitucionalidade por omissão, que muitas vezes causa entraves para a efetivação de direitos e garantias fundamentais assegurados pelo texto constitucional. O presente caso oferece uma oportunidade para que o Tribunal avance nesse sentido24 (Destaque nosso).

Contudo, recentemente foi editada a Súmula Vinculante 37, que dispõe não caber "ao Poder Judiciário, que não tem função legislativa, aumentar vencimentos de servidores públicos sob o fundamento de isonomia"25.

Mas no que consiste esse dogma? A partir da concepção da corte em seu desenho institucional primário, isto é, a partir da ideia derivada de Kelsen26, de que o papel da jurisdição constitucional seria restrito a excluir do ordenamento jurídico as normas ou trechos de normas incompatíveis com as disposições constitucionais 27.

Na qualidade de "legislador negativo", o Supremo Tribunal Federal assumiria, destarte, a função de, por assim dizer, minimalista jardineiro fiel do ordenamento jurídico pátrio, pronto a eliminar (rectius: derrogar ou cassar), em sede do controle abstrato, eventuais ervas daninhas surgidas no campo constitucional, o qual, porém, a priori e em definitivo,

\footnotetext{
24 A argumentação do Ministro foi assim fundamentada: "o vazio jurídico a ser produzido por uma decisão simples de declaração de inconstitucionalidade/nulidade dos dispositivos normativos impugnados - principalmente as normas de transição contidas no artigo 57 - torna necessária uma solução diferenciada, uma decisão que exerça uma "função reparadora" ou, como esclarece Blanco de Morais, "de restauração corretiva da ordem jurídica afetada pela decisão de inconstitucionalidade ${ }^{\prime \prime \prime}$. BRASIL. Supremo Tribunal Federal. ADI 1.351, Rel. Min. Marco Aurélio, j. 07/12/2006. Voto do Ministro Gilmar Mendes, p. 160. Diário de Justiça da União. Brasília, DF, 29 jun. 2007. Disponível em: http://redir.stf.jus.br/paginadorpub/paginador.jsp?docTP=AC\&doclD=416150 Acesso em: 1 nov. 2012.

25 Referido enunciado reproduz os termos da Súmula 339, editada em conformidade com o Regimento Interno do STF, constantemente empregada nas demandas de servidores públicos dos anos 90 e 2000 perante os tribunais brasileiros.

26 BRANDÃO, Rodrigo. O STF e o dogma do legislador negativo. Direito, Estado e Sociedade, Rio de Janeiro, n.44, 2014.

27 DIAS, Gabriel Nogueira. "Legislador negativo" na obra de Hans Kelsen: origem, fundamento e limitações à luz da própria Reine Rechtslehre. Revista Brasileira de Estudos Constitucionais - RBEC. Belo Horizonte, ano 4, n. 15, jul. / ago., 2010.
} 
já teria sido semeado bem ou mal através das palavras do legislador constitucional competente28.

Verifica-se, nos precedentes em que os membros do Tribunal invocaram tal dogma, uma indisposição institucional quanto à adoção de condutas que poderiam ser caracterizadas como criação judicial de direito, ou seja, uma postura de “legislador positivo", v.g., reformando decisões legislativas anteriormente tomadas pelo Parlamento ou, em paralelo à atividade de controle, acrescentando, via mecanismos hermenêuticos, normas cuja expressão literal inexiste no texto constitucional.

Em sua postura seletiva quanto à escolha dos casos a decidir, isto é, entre as dimensões de árbitro, de ativista ou de instituição autocontida, o Tribunal rotineiramente alterna, em comportamento estratégico compatível com os diálogos institucionais, sua postura frente aos hard cases constitucionais, dependendo, por exemplo, do contexto econômico ou do tema envolvido em sua agenda de julgamentos, ora invocando o dogma para eximir-se de decidir (ex. Al 360461 AgR29), ora superando o dogma total ou parcialmente para decidir em flagrante atividade criativa legiferante (ex: PET n 3.388, DJ, 25/09/2009, Caso Raposa Serra do Sol).

\subsection{Reconhecimento da separação entre os poderes: atos interna corporis do Legislativo e "reserva da Administração"}

Com relação às normas regimentais, tenho várias decisões e endosso integralmente a jurisprudência da Corte no sentido de que se trata, realmente, de eventual violação de normas regimentais, de uma questão interna corporis. Eo faço pedindo vênia a Vossa Excelência até quanto ao que traz: mas, numa convenção de condomínio, poderemos ou não examinar; mas o que é deliberado no Parlamento não, em termos de normas regimentais, porque acho que se faz em homenagem ao artigo $2^{\circ}$ da Constituição da República, que diz, como sabemos, que os Poderes são harmônicos e independentes ao princípio da separação dos Poderes.

Ministra Rosa Weber, MS 31816 MC-AgR, 2013 (Destaque nosso).

\footnotetext{
28 DIAS, Gabriel Nogueira. "Legislador negativo" na obra de Hans Kelsen: origem, fundamento e limitações à luz da própria Reine Rechtslehre. Revista Brasileira de Estudos Constitucionais - RBEC. Belo Horizonte, ano 4, n. 15, jul. / ago., 2010.

29 Os magistrados e Tribunais, que não dispõem de função legislativa - considerado o princípio da divisão funcional do poder -, não podem conceder, ainda que sob fundamento de isonomia, isenção tributária em favor daqueles a quem o legislador, com apoio em critérios impessoais, racionais e objetivos, não quis contemplar com a vantagem desse benefício de ordem legal. Entendimento diverso, que reconhecesse aos magistrados essa anômala função jurídica, equivaleria, em última análise, a converter o Poder Judiciário em inadmissível legislador positivo, condição institucional que lhe recusa a própria Lei Fundamental do Estado. Em tema de controle de constitucionalidade de atos estatais, o Poder Judiciário só deve atuar como legislador negativo. Precedentes.(BRASIL, STF, AI 360461 AgR, Relator(a): Min. CELSO DE MELLO, Segunda Turma, julgado em 06/12/2005, DJe 27/03/2008).
} 
A sindicabilidade judicial sobre as decisões tomadas no âmbito dos parlamentos refere-se à defesa dos denominados interna corporis do Poder Legislativo, sobretudo no que concerne à materialidade da norma violada. Para Hely Lopes Meirelles, que defendia a possibilidade de controle dos atos apenas no que se refere às disposições formais ou procedimentais estabelecidas na Constituição, nas leis e também nos regimentos:

Interna corporis são só aquelas questões ou assuntos que entendem direta e imediatamente com a economia interna da corporação legislativa, com seus privilégios e com a formação ideológica da lei, que, por sua própria natureza, são reservados à exclusiva apreciação e deliberação do Plenário da Câmara. ${ }^{30}$

As impressões variam, desde o reconhecimento da imunidade dos atos lastreados nos regimentos das casas, passando pela possibilidade de controle restrito aos atos internos que contrariem os procedimentos formais estabelecidos na Constituição e, por fim, alguns autores defendem o controle judicial sobre os atos violadores das disposições regimentais dos ritos parlamentares ${ }^{31}$.

A garantia das cláusulas pétreas é o argumento mais forte para a intervenção judicial, na compreensão de que o "fundamento para essa exceção é garantir o "núcleo inalterável da Constituição", de sorte que o projeto de emenda que afronte o art. 60, § $4^{\circ}$, da Carta Magna não pode sequer ser recebido pelo Congresso Nacional, devendo ser imediatamente indeferido" 32 .

De toda sorte, a intervenção judicial também passa por uma importante questão, a natureza jurídica das normas regimentais, atribuição normativa das casas parlamentares, decorrente de expressa previsão constitucional - art. 51, III, no caso da Câmara dos Deputados e art. 52, XII, no que se refere ao Senado Federal - e que explicitam a independência no Poder Legislativo para o exercício das suas funções.

Diante das características específicas das atribuições parlamentares, referidos regimentos contemplam "questões referentes à distribuição das matérias, regime de tramitação, prejudicialidade, desarquivamento de proposições, interstício, turnos, retirada de pauta, limitação material do poder conclusivo das comissões e funcionamento das CPIs", dentre outros33. A proteção dos atos interna corporis é constantemente

\footnotetext{
30 MEIRELLES, Hely Lopes. Direito administrativo brasileiro. 28 ed. São Paulo, Malheiros, 2003. p. 683.

31 SILVA FILHO, Derly Barreto e. Controle dos atos parlamentares pelo Poder Judiciário. São Paulo: Malheiros Editores, 2003, passim.

32 AGRA, Walber de Moura. Curso de direito constitucional. $8^{\text {a }}$ ed. Rio de Janeiro: Forense, 2014 , p.679.

33 SILVA FILHO, Derly Barreto e. Controle dos atos parlamentares pelo poder judiciário. São Paulo: Malheiros Editores, 2003, p. 73.
} 
invocada pelo Tribunal na análise dos mandados de segurança dos parlamentares, a ratificar sua opção pela não interferência nestes temas ${ }^{34}$.

Já no que se refere ao controle de políticas públicas, a autorrestrição inscreve sua relevância na defesa da "reserva da administração". Com efeito, a discricionariedade administrativa refere-se à determinação dos critérios, na existência de uma espécie de reserva da Administração, que se oporia à "reserva de lei".

Em rápidas palavras, pode-se definir a reserva da Administração como "uma esfera em que, de um ponto de vista negativo, a Administração estaria livre de ingerências de legislação, e, de um ponto de vista positivo, seria ela própria a determinar, vinculada apenas ao quadro constitucional, os correspondentes objetivos, tarefas e atividades" das matérias a ela submetidas ${ }^{35}$. Em constituições complexas e analíticas, estabelece-se uma tensão entre "discricionariedade administrativa" - que protegeria as opções técnicas dos gestores públicos, constantemente limitados pelo reconhecimento da escassez 36 inerente à prestação material de direitos, sobretudo em virtude do seu elevado custo - e a garantia do "núcleo essencial" de direitos fundamentais -que, nos quadros de um neoconstitucionalismo, redefiniriam a noção de uma vinculatividade dos poderes públicos ${ }^{37}$, especialmente dos administradores.

Não por acaso, para Maria Paula Dallari Bucci, “(o) desafio reside em estabelecer uma metodologia apropriada para o trabalho jurídico, que permita descrever e compreender, segundo as categorias do Direito, uma ação governamental determinada e analisar juridicamente o seu processo de formação e implementação"38

O STF, entretanto, possui a opção de prestigiar as escolhas do administrador público:

(...) consoante a jurisprudência da Corte, a concessão de isenção tributária configura ato discricionário. Por meio dela, o Poder Público, embasado no juízo de conveniência e oportunidade - o que inclui a verificação do momento adequado para a concretização da benesse fiscal -, busca efetivar políticas fiscais e econômicas. Não cabe, assim, ao Poder Judiciário, sob pena de ofensa ao princípio da separação dos poderes, afirmar

\footnotetext{
34 LIMA, Flávia Danielle Santiago. Perdedores no Congresso Nacional e no STF? A judicialização das questões interna corporis do Legislativo. Revista Jurídica da Presidência, Brasília, v. 18, p. 307-330, 2016. p. 320-322.

35 NOVAIS, Jorge Reis. Separação de poderes e limites da competência legislativa da Assembléia da República: simultaneamente um comentário ao Acórdão n. $1 / 97$ do Tribunal Constitucional. Lisboa: Lex, 1997, p. 33-34.

36 AMARAL, Gustavo. Direito, escassez e escolha: critérios jurídicos para lidar com a escassez de recursos e as decisões trágicas. 2. ed. Rio de Janeiro: Lumen Juris, 2010.

37 BARCELLOS, Ana Paula de. Neoconstitucionalismo, Direitos fundamentais e controle das políticas públicas. Disponível em <http://www.mundojurídico.adv.br/cgibin/upload/texto853.pdf. >. Acesso em 1 nov 2015.

38 BUCCI, Maria Paula Dallari. Notas para uma metodologia jurídica de análise de políticas públicas. In: FORTINI, Cristiana; ESTEVES, Julio César dos Santos; DIAS, Maria Tereza Fonseca (Org.). Políticas públicas: possibilidades e limites. Belo Horizonte: Fórum, 2008.
} 
que determinada situação está abrangida por uma norma de isenção tributária se assim ela não determinou. Sobre o assunto: Al no 360.461/MG-AgR, Segunda Turma, Relator o Ministro Celso de Mello, DJe de 28/3/08; RE no 344.331/PR, Primeira Turma, Relatora Ministra Ellen Gracie, DJ de 14/3/03.

Ministro Dias Toffoli - MS 34342 AgR, 2017 (Destaque nosso).

\section{AUTORRESTRIÇÃO FORMAL EXPRESSA (OU VIRTUDES PASSI- VAS)? ILEGITIMIDADE ATIVA, PERTINÊNCIA TEMÁTICA, COM- PETÊNCIA E REQUISITO DE SUBSIDIARIEDADE NO STF.}

Noutro cenário, Bickel explora e traz à luz o uso das chamadas virtudes passivas, técnicas de adjudicação que permitem ao tribunal, no emprego da sua prudência, agir estrategicamente na perseguição das suas responsabilidades 39 .

As virtudes passivas são argumentos jurídicos - geralmente de cunho processual - que facultam à corte eximir-se da apreciação de um caso que lhe fora submetido. Assim, pode afirmar a sua incompetência para decidir, a ausência de legitimidade ativa do requerente, a "falta de maturação" da causa, lançar mão da doutrina das "questões políticas", dentre outros argumentos típicos do sistema judicial norte-americano, ainda que assemelhados às construções processuais de outros ordenamentos ${ }^{40}$.

Para ele, essas técnicas constituem instrumentos à disposição dos juízes, deixando às instituições eleitorais a condução da política, ao excluírem-se desta. Ao utilizar este expediente, o tribunal agiria como um "animal político"41.

A vantagem inicial do emprego destas técnicas parece assentada: evitar que a corte posicione-se definitivamente, em prejuízo da sua função de guardiã dos princípios, ou confronte a opinião pública e os poderes majoritários. Ao deixar a questão em aberto, mantém-se fiel aos seus compromissos 42 .

Apesar de discorrer longamente sobre estas virtudes passivas, apontando as diferenças entre estas técnicas, Bickel não apresenta padrões ou princípios que auxiliem o tribunal na opção entre seu emprego ou não, tampouco na escolha do "instrumento"

\footnotetext{
39 BICKEL, Alexander M. The least dangerous branch: the Supreme Court at the bar of politics. Indianapolis: Bobbs-Merrill, 1962, p. 105-111.

40 Destacam-se, entre os requisitos para análise de um tema pela Suprema Corte, elementos como "cases and controversies" (delimitação da temática de ordem constitucional), "standing to sue" (a prova do interesse da parte na solução do conflito), "precedent" ou "stare decisis" (a vinculação às decisões anteriormente proferidas), "comity" (esgotamento das instâncias prévias) e as já debatidas "political questions" (deve-se demonstrar que se trata de um debate eminentemente jurídico).

${ }^{41}$ BICKEL, Alexander M. The Supreme Court, 1960 Term - foreword: the passive virtues. Harvard Law Review, Cambridge, n. 75 , p. 40-75, nov. 1961. p. 51.

42 Embora Bickel não seja expresso nesse sentido, Lima entende que o princípio democrático também prevalece quando a corte opta por utilizar as "virtudes passivas", pois a não apreciação da demanda mantém o ato questionado no ordenamento: LIMA, Flávia Danielle Santiago. Jurisdição constitucional e política: ativismo e autocontenção no STF. Curitiba: Juruá, 2014.LIMA, Flávia Danielle Santiago. Jurisdição constitucional e política: ativismo e autocontenção no STF. Curitiba: Juruá, 2014
} 
a ser utilizado43. Tal questão também não envolveria sabedoria acadêmica, mas habilidade na arte do "compromisso" e uma "familiaridade com as formas", ou, como prefere o próprio autor, o exercício da arte da prudência, distinto do juízo de princípio 44 .

Ao não julgar, é possível que a corte explore o"maravilhoso mistério do tempo"45, em suas diversas implicações. Por vezes, na oportunidade posterior de julgamento, pode-se concluir que chegou o momento de abordar diretamente a questão, mesmo que fundamentada em princípio contrário à expectativa popular. Para mitigar o impacto da decisão contrária às maiorias, Bickel sugere o uso de "instrumentos retóricos"46.

\subsection{Restringindo 0 acesso à jurisdição constitucional: a ilegitimidade ativa e o"filtro" da pertinência temática em sede de ação direta}

Consoante assentado na decisão agravada, a autora não se insere em qualquer das hipóteses do art. 2, IX, da Lei 9.868/1999, o qual, reproduzindo o teor do art. 103, IX, da Lei Maior, assegura legitimidade ativa especial (i) às confederações sindicais e (ii) às entidades de classe de âmbito nacional para impugnar, mediante ação direta, a constitucionalidade de dispositivos de lei ou de ato normativo. Isso porque a autora, de um lado, não se confunde com as confederações ao feitio dos arts. 103, IX, da Constituição da República e 2, IX, da Lei no 9.868/1999, sabidamente entidades integrantes - no grau máximo - da estrutura sindical - representativas, em todo o território nacional de interesses de categorias profissionais ou econômicas. De outro, enquanto entidade de administração do desporto, tampouco se enquadra como entidade de classe, a teor da parte final dos dispositivos citados. Pessoa jurídica de direito privado e sem fins lucrativos, apresenta-se, a autora, como entidade de classe de âmbito nacional, a congregar federações estaduais de atletismo. Todavia, constitui entidade nacional de administração do desposto, de perfil e natureza fundamentalmente diversos. (...) Ausente a legitimatio ad causam ativa, delineia-se a carência da ação, a conduzir à extinção do feito sem resolução do mérito.

Min. Rosa Weber, ADPF 406, 2016 (Destaque nosso).

\footnotetext{
43 "The passive devices that I have canvassed do not produce constitutional decisions. They do nor check or legitimate on principle. They are not themselves principled, they do not operate independently, and the variables that render them decisive cannot be contained in any principle". BICKEL, Alexander M. The least dangerous branch: the Supreme Court at the bar of politics. Indianapolis: Bobbs-Merrill, 1962, p. 205.

44 BICKEL, Alexander M. The least dangerous branch: the Supreme Court at the bar of politics. Indianapolis: Bobbs-Merrill, 1962, p. 26.

45 BICKEL, Alexander M. The least dangerous branch: the Supreme Court at the bar of politics. Indianapolis: Bobbs-Merrill, 1962, p. 26.

46 BICKEL, Alexander M. The least dangerous branch: the Supreme Court at the bar of politics. Indianapolis: Bobbs-Merrill, 1962, p. 188.
} 
Como visto anteriormente, as virtudes passivas são estratégias de autocontenção que procuram embasamento em questões formais, de natureza procedimental, para justificar o não julgamento de litígios constitucionais. Dentre estas, está a verificação da legitimidade ativa para a causa (ad causam), isto é, da existência de expressa autorização legal para que o ator, individual ou coletivo, possa exercer o seu direito de ação, provocando o Poder Judiciário para intervir em determinado conflitos de interesses 47 , in casu, nos conflitos acerca da constitucionalidade de normas jurídicas e/ou de atos praticados por agentes públicos.

Entretanto, tal instituto de direito processual foi concebido originalmente pensando-se em demandas de natureza subjetiva, nos quais se resolvem conflitos entre duas partes; por sua vez, no exercício da revisão judicial concentrada, cujo objeto são processos objetivos (de natureza institucional), o conteúdo da legitimidade ativa ganha contornos específicos: trata-se de uma espécie de legitimação extraordinária restrita aos ao elenco de atores previsto no artigo 103 da Constituição Federal, expressivamente ampliado em relação aos textos constitucionais anteriores 48 .

Neste sentido, o então Ministro Moreira Alves assim já afirmou: “Eu não conheço - talvez seja ignorância minha - nenhum país de controle concentrado que tenha uma lista de legitimados ativos como aquela que se encontra no art.103 da CF"49. Tal declaração ilustra posicionamento restritivo de muitos membros da corte, que se empenharam numa delimitação duradoura e, muitas vezes, inflexível da legitimidade ativa, bem como no bloqueio de posteriores tentativas de ampliação do rol pela via interpretativa50.

Num cenário institucional caracterizado por um desenho constitucional que, contextualizado por aspirações de abertura democrática, maximizou a relação de atores autorizados a levar questões litigiosas para serem resolvidas, de modo concentrado, pelo Supremo Tribunal Federal, é possível identificar uma clara postura dos membros da corte, voltada a reagir contra qualquer tentativa de ampliar ainda mais este acesso à jurisdição constitucional.

Vide que não há correlação entre as normas impugnadas, que dizem respeito à concessão de benefícios fiscais relativos ao ICMS, e os objetivos institucionais perseguidos pela autora, que estão voltados, em suma, para entidades sindicais e trabalhadores

\footnotetext{
47 CINTRA, Antonio Carlos de Araújo; GRINOVER, Ada Pellegrini; DINAMARCO, Cândido Rangel. Teoria Geral do Processo. São Paulo, Malheiros, 2016.

48 BARROSO, Luís Roberto. 0 controle de constitucionalidade no direito brasileiro. São Paulo, Saraiva, 2008. p.152-153.

49 ALVES, José Carlos Moreira. Força vinculante das decisões do Supremo. Declaração de constitucionalidade. Juizados Especiais. Valorização dos recursos processuais. Revista dos Tribunais, São Paulo, ano 5, n. 18, 1997. p.276.

50 CARVALHO, Ernani. Dimensão política do acesso à justiça: aspectos da revisão judicial. In: GOMES NETO, José Mário Wanderley (Org.). Dimensões do Acesso à Justiça. Salvador, Editora PODIVM, 2008. p.46.
} 
inorganizados em sindicatos nas indústrias metalúrgicas, mecânicas e de material elétrico, eletrônico e de informática. De mais a mais, os interesses por ela abrangidos não são atingidos de maneira direta pelos dispositivos questionados. Ausente, portanto, o requisito da pertinência temática, o que afasta o conhecimento da ação.

Min. Dias Toffoli, ADI 4722, 2016 (Destaque nosso).

No desenho constitucional brasileiro, estão autorizados a propor as ações do controle direto de constitucionalidade o Procurador-Geral da República, o Presidente da República, as Mesas do Senado Federal, da Câmara dos Deputados, das Assembleias Legislativas dos Estados e do Distrito Federal, os Governadores, o Conselho Federal da Ordem dos Advogados do Brasil (OAB), os partidos políticos, as confederações sindicais e as entidades de classe com âmbito nacional (art. 103). As preocupações em torno do excesso de demandas, sobretudo dos atores da sociedade civil sempre foram grandes.

Para reduzir o quantitativo de demandas, criou-se, portanto, na jurisprudência do STF, o instituto da pertinência temática para alguns dos legitimados ativos, como meio de impor limites ao acesso efetivo. Governadores e as Mesas das Assembleias Legislativas dos Estados passaram a ter de obedecer à nova regra, e entidades de classe e confederações sindicais tiveram seus conceitos minimamente disciplinados.

Ao longo dos anos de vigência da Nova Carta, e independentemente de qualquer norma expressa, a jurisprudência do Supremo Tribunal Federal consolidou uma distinção entre duas categorias de legitimados: (i) os universais, que são aqueles cujo papel institucional autoriza a defesa da Constituição em qualquer hipótese; e (ii) os especiais, que são órgãos e entidades cuja atuação é restrita às questões que repercutem diretamente sobre sua esfera jurídica ou de seus filiados e em relação às quais possam atuar com representatividade adequada51.

O requisito da pertinência temática impulsionou a necessidade de identificação de nexo entre a norma impugnada e as atividades institucionais dos requerentes (aqueles a quem a jurisprudência exige relação de pertinência) como condição de admissibilidade do processo de controle concentrado.

Nas discussões sobre legitimidade efetiva para propor ação direta de constitucionalidade gerou-se uma disputa, dentro do Supremo Tribunal Federal, sobre a necessidade, ou não, de restringir ao máximo tal legitimidade. A jurisprudência tem dado vitória aos

51 BARROSO, Luís Roberto. 0 controle de constitucionalidade no direito brasileiro. São Paulo, Saraiva, 2008. p.152-153. 
ministros que são a favor da restrição. Foi criada, em alguns casos, como por exemplo, dos Governadores e Assembléias Legislativas, a relação de pertinência52.

Trata-se de efetivo e eficiente mecanismo de filtro processual a serviço da autorrestrição judicial, que evita o julgamento de questões em que os requerentes (legitimados) especiais quedaram derrotados em seus pleitos por não serem capazes de demonstrar (ou fazer aceita a alegada) identidade (relação lógica) entre objeto do processo (norma jurídica ou ato administrativos sujeitos à impugnação) e as matérias relativas à sua competência legislativa e/ou os objetivos sociais da entidade responsável por propor a ação53.

\section{2. (Re)definindo sua própria jurisdição: competência originária e o requisito da subsidiariedade para arguição de descumprimento de preceito fundamental}

Relembre-se que esta Corte (...) entendia que a demanda relativa ao recebimento de ajuda de custo por magistrado, por envolver interesse de toda Magistratura nacional, atrairia a competência originária desta Corte, nos termos do disposto no art. 102, I, " $n$ ", da CF. Após o julgamento da referida reclamação, a jurisprudência da Corte foi paulatinamente alterada. Fixou-se o posicionamento pela inaplicabilidade do art. 102, I, "n", da CF de 1988 às demandas relativas ao pagamento de ajuda de custo a magistrados, em razão da inexistência de interesse específico ou exclusivo de todos os membros da Magistratura. Sintetizando: a competência do STF de que trata o art. 102, I, " $n$ ", da Constituição Federal apenas se configura nas demandas que atinjam toda a Magistratura, direta ou indiretamente, e naquelas em que haja interesse exclusivo da categoria, deixando de lado as que discutam peculiaridades, as que digam respeito a número restrito de seus integrantes e as demais questões de interesses coligados com outras categorias.

Min. Gilmar Mendes, AO 1953 AgR, 2017 (Destaque nosso).

Outro aspecto do prisma procedimental a serviço das virtudes passivas e, por consequência, da fundamentação em supostas questões de forma (vícios processuais) que justificam o comportamento autorrestrito do Supremo Tribunal Federal,

\footnotetext{
52 CARVALHO, Ernani. Dimensão política do acesso à justiça: aspectos da revisão judicial. In: GOMES NETO, José Mário Wanderley (Org.). Dimensões do Acesso à Justiça. Salvador, Editora PODIVM, 2008. p.46.

53 BARROSO, Luís Roberto. $O$ controle de constitucionalidade no direito brasileiro. São Paulo, Saraiva, 2008. p.159.
} 
é a discussão sobre o âmbito de competência originária da corte, isto é, o espectro de litígios cuja temática, por sua relevância, têm acesso à jurisdição constitucional concentrada.

Com sede na Capital da União e competência sobre todo o território nacional (Consti., art.92, par.ún.), o Supremo Tribunal Federal representa o ápice da estrutura judiciária nacional e articula-se quer com Justiça comum, quer com as especiais. (...) Sua função básica é a de manter o respeito à Constituição e sua unidade substancial em todo país, o que se faz através de uma série de mecanismos diferenciados - além de encabeçar o Poder Judiciário inclusive em certas causas sem conotação constitucional54.

Neste diapasão, a corte tem sido refratária a sucessivas tentativas de ampliação da sua competência originária fixada na Constituição (art.102, incisos I, "a" até "r", II, "a" e "b", e III, "a" até "d"), repelindo, quando Ihe convém, manobras interpretativas que acrescentem em sua agenda de julgamentos questões litigiosas outras, ao seu sentir, da competência de outros órgãos judiciários.

Exemplificando tais situações, tem-se a rejeição dos mandados de segurança impetrados contra ato de deliberação negativa do Conselho Nacional de Justiça55 e das ações cíveis originárias que pretendiam a apreciação de conflitos relativos à gestão de estradas pela iniciativa privada, a partir de concessões estaduais de serviço público, por inexistência de conflito federativo ${ }^{56}$.

Outra virtude passiva, fruto da jurisprudência da corte suprema sobre o artigo 4o, §10, da Lei n. 9.886/99, que visa a ser filtro procedimental ao crescimento das hipóteses de revisão judicial concentrada, é o requisito de subsidiariedade, exigido em relação à propositura das arguições por descumprimento de preceito fundamental (ADPF).

A jurisprudência do STF firmou-se no sentido de que a arguição de descumprimento de preceito fundamental possui como requisitos processuais a relevância constitucional da controvérsia e o critério da subsidiariedade. (...) Sendo assim, verifica-se que a questão

\footnotetext{
54 CINTRA, Antonio Carlos de Araújo; GRINOVER, Ada Pellegrini; DINAMARCO, Cândido Rangel. Teoria Geral do Processo. São Paulo, Malheiros, 2016, p.179.

55 O Supremo Tribunal Federal firmou orientação no sentido de que não lhe compete julgar, em caráter originário, o mandado de segurança que impugne deliberação negativa do Conselho Nacional de Justiça (BRASIL, SUPREMO TRIBUNAL FEDERAL, MS 34213 AgR, Relator(a): Min. EDSON FACHIN, Primeira Turma, julgado em 27/09/2016, PROCESSO ELETRÔNICO DJe-017 DIVULG 31-01-2017 PUBLIC 01-02-2017).

56 "Estadualização" da gestão de trechos de rodovias federais. remessa dos autos a esta corte. Inexistência de conflito federativo. Incompetência do Supremo Tribunal Federal. Devolução dos autos à origem. Agravos regimentais a que se nega provimento (BRASIL, SUPREMO TRIBUNAL FEDERAL. ACO 2827 AgR, Relator(a): Min. TEORI ZAVASCKI, Tribunal Pleno, julgado em 31/08/2016, ACÓRDÃO ELETRÔNICO DJe-260 DIVULG 06-12-2016 PUBLIC 07-12-2016).
} 
posta em juízo já foi resolvida de forma eficaz e geral pela via da sistemática da repercussão geral, como pretendia por esta ADPF a parte Arguente, embora de forma contrária a seus interesses, o que corrobora os fundamentos da decisão impugnada no sentido do não preenchimento do requisito da subsidiariedade.

Min. Edson Fachin, ADPF 145 AgR, 2017 (Destaques nossos).

Em virtude de tal requisito, somente são admitidas as ADPFs quando não houver qualquer outro meio eficaz de sanar a alegada lesividade ao preceito fundamental objeto do conflito constitucional, deixando ao órgão julgador ampla margem de subjetividade quanto à definição, naquele caso concreto, da extensão do requisito subsidiariedade.

A doutrina e a própria jurisprudência do Supremo Tribunal Federal têm oscilado na compreensão desse dispositivo, gerando manifestações antagônicas. A matéria não é singela. (...) [De modo geral, se] rejeita a arguição sempre seja possível enfrentar o ato por via de mandado de segurança, ação popular, reclamação ou recursos ordinários e extraordinários, pelo menos antes que eles sejam esgotados. (...) A questão central está na eficácia do "outro meio" referido na lei, isto é, no tipo de solução que é capaz de produzir. Considerando que a decisão na ADPF é dotada de caráter vinculante e contra todos, quando esses efeitos forem decisivos para o resultado que se deseja alcançar, dificilmente uma ação individual ou coletiva de natureza subjetiva poderá atingi-lo. (...) [O] exame de sua subsidiariedade deve levar em consideração os demais processos objetivos já consolidados no sistema constitucional. Isso porque, embora seja possível imaginar exceções pontuais, os efeitos da atuação judicial nas vias ordinárias limitam-se, em regra, às partes 57 .

Isto lhe permite clara liberdade interpretativa para identificar a existência de outros instrumentos procedimentais de impugnação do ato contestado ou para caracterização da ADPF, naquele momento, como último remédio a proteger o preceito fundamental ante à lesão ou à ameaça decorrente do ato submetido ao julgamento pela corte.

57 BARROSO, Luís Roberto. 0 controle de constitucionalidade no direito brasileiro. São Paulo, Saraiva, 2008. p.275-276. 


\section{AUTORRESTRIÇÃO “TÁCITA": O SILÊNCIO COMO RESPOSTA DA CORTE}

Em outras situações, o Tribunal adia a resposta porque possui dúvidas quanto ao princípio controlador ou sobre seu sentido. Embora os princípios constitucionais sejam duradouros, sua formulação projeta dúvidas sobre as consequências futuras das decisões judiciais, caso tomadas no cenário existente naquele momento.

Para solucionar sua incerteza, emprega soluções provisórias, que lhe permitem avaliar as reações do público e dos agentes governamentais, de sorte a construir seu entendimento. Assim, ao invés de simplesmente postergar o debate, a corte desempenha uma função pedagógica, utilizando essas decisões provisórias como uma estratégia de persuasão lenta, para avançar com ideias que já articula em sua forma final ${ }^{58}$.

Segundo argumento de Bickel, a conduta estratégica da corte pressupõe que o período posterior à decisão seja aproveitado para a construção de um diálogo ou, como prefere o autor, um "colóquio" entre os ramos de governo acerca das questões de princípio envolvidas. Deste modo, ao optar por não decidir, é possível que a "tensão lincolniana" seja atenuada ou até dirimida por estes diálogos, e o tribunal alcance uma melhor compreensão das questões envolvidas, para sua adequada resolução59. Quando, finalmente, decide julgar, pode haver uma aceitação generalizada do resultado ou uma redução considerável de custos políticos e/ou econômicos no decidir, pois o debate já estaria amadurecido na opinião pública ou nas searas legislativas60.

\subsection{Aguardando julgamento: estratégia ou esquecimento?}

Em números mais recentes, do universo total de 5.680 ações diretas de inconstitucionalidade distribuídas até o dia 7 de abril de 2017, uma parcela de 1.912 processos (34,69\%) permanecia aguardando julgamento61.

Por outro lado, uma outra provável estratégia tácita para evitar o julgamento imediato de questões politicamente relevantes e que possam, naquele momento

\footnotetext{
58 BICKEL, Alexander M. The least dangerous branch: the Supreme Court at the bar of politics. Indianapolis: Bobbs-Merrill, 1962, p. 26.

59 BICKEL, Alexander M. The least dangerous branch: the Supreme Court at the bar of politics. Indianapolis: Bobbs-Merrill, 1962 , p. 206-261.

$60 \mathrm{Em}$ trabalhos posteriores, Bickel manteve sua crença no processo político e sua capacidade de promover a defesa ou participação de todos os grupos. KECK, Thomas M..The most activist Supreme Court in history: the road to modern judicial conservatism. Chicago: The University of Chicago Press, 2004, p. 98.

61 GOMES NETO, José Mário Wanderley et al. LITÍGIOS ESQUECIDOS: Análise empírica dos processos de controle concentrado de constitucionalidade aguardando julgamento. Revista de Estudos Empíricos em Direito, v.4, n.2, p.75-86, 2017.
} 
impor custos indesejados aos membros do tribunal, seria simplesmente retardar o momento da decisão para um período posterior. Conforme Joaquim Falcão, “O Supremo seria um tribunal político não apenas porque concorda ou discorda do Executivo ou do Congresso. Mas antes porque controla o tempo de concordar ou discordar"62.

Os Ministros Relatores, a quem compete a atribuição de julgar monocraticamente os procedimentos (quando cabível) ou de incluir as questões em pauta para julgamento colegiado, postergam a prática destes atos para outros pontos de apreciação no tempo futuro, nos quais o cálculo dos custos institucionais Ihes seja mais favorável.

A apreciação do caso e o momento das decisões possuem inevitáveis repercussões políticas: um juiz que possua formação política, notadamente aquele componente de uma Suprema Corte, indicado por um partido político , e cuja decisão esteja orientada estrategicamente deve estar preparado para sopesar os custos e benefícios de suas decisões e de seus esforços de influência63 (Destaque nosso).

Significativa fração do universo de processos da jurisdição constitucional é silenciosamente excluída da apreciação da jurisdição constitucional, no âmbito do STF, dá indícios do exercício de seletividade quanto ao julgamento dos conflitos, fomentando indagações quanto às situações que estariam associadas a maiores ou menores chances de resolução dos litígios constitucionais ou de longos períodos de espera por um pronunciamento acerca da alegada inconstitucionalidade da norma impugnada64.

\subsection{Perda de objeto (bloco de constitucionalidade/emenda, altera- ção legislativa): efeitos do tempo sobre a pretensão.}

Conforme consignei na decisão agravada, na presente ação direta de inconstitucionalidade são impugnadas determinadas normas constantes da Lei no 11.000/04, as quais, em suma, autorizam os conselhos de fiscalização de profissões regulamentadas a fixar, a cobrar e a executar contribuições anuais devidas por pessoas físicas ou jurídicas. Todavia, as normas ora questionadas foram tacitamente revogadas pela Lei n 12.514/11, a

\footnotetext{
62 FALCÃO, Joaquim. O Supremo: compreenda o poder, as razões e as consequências das decisões da mais alta Corte do Judiciário no Brasil. Rio de Janeiro: Fundação Getúlio Vargas, 2015. p. 93.

63 GOMES NETO, José Mário Wanderley Gomes; LIMA, Flávia Danielle Santiago. Poder de agenda e estratégia no STF: uma análise a partir da decisão liminar nos mandados de segurança n 34.070 e n 34.071. In: MARTINS, Argemiro Cardoso Moreira et al. (Orgs.). Constituição e Democracia II. Florianópolis, CONPEDI, 2016.

64 GOMES NETO, José Mário Wanderley et al. LITÍGIOS ESQUECIDOS: Análise empírica dos processos de controle concentrado de constitucionalidade aguardando julgamento. Revista de Estudos Empíricos em Direito, v. 4, n. 2, p. 75-86, 2017.
} 
qual, conforme sua ementa, "trata das contribuições devidas aos conselhos profissionais em geral". Vide que os temas relativos à fixação, à cobrança e à execução das anuidades são tratados, notadamente, pelos arts. $3^{\circ}$ a $9^{\circ}$ da nova lei. Repare-se, aliás, que a própria requerente concorda haver, "efetivamente, (...) lei posterior que revogou os dispositivos da lei vergastada". Consoante a jurisprudência da Corte, considera-se prejudicada a ação direta de inconstitucionalidade por perda superveniente de objeto quando sobrevém a revogação da norma questionada.

Min. Dias Toffoli, ADI 3408 AgR, 2016 (Destaque nosso).

O que viria a ser a alegada perda superveniente do objeto e como esta circunstância seria expressão de uma autocontenção tácita da corte? Trata-se uma questão formal (técnico-processual), prevista na legislação processual civil brasileira, relacionada à formação e à continuidade válidas de um processo (consequentemente às virtudes passivas tácitas): 0 interesse processual.

$O$ interesse processual diz respeito à necessidade e à utilidade do julgamento de um processo por um órgão individual ou colegiado do Poder Judiciário: a propositura de uma ação significa a provocação (chamado) do Poder Judiciário para que interfira em um conflito de interesses, caracterizado pelo suposto descumprimento pela parte contrária de uma norma, seja estatal ou seja contratual.

Devem os órgãos judiciais, desse modo, verificar a presença de um conflito a ser solucionado, como condição para a formação e para a continuidade válida de um processo, notadamente daqueles que tratam da jurisdição constitucional. Nestes termos, a hipótese do encerramento posterior (por qualquer motivo) de um litígio existente caracterizaria um grave defeito formal, que levaria imediatamente à extinção (encerramento) do processo e prejudicaria o julgamento da questão controversa, evitando processos injustificáveis ou que não possuam utilidade social.

O Poder Judiciário, em tese, estaria impossibilitado de julgar a questão que lhe foi submetida, em virtude da verificação de fatos ocorridos durante o processo, cujas consequências, em tese, encerrariam o litígio. Desaparecia, portanto, o interesse processual quando não se pudesse mais extrair qualquer utilidade a partir do julgamento do processo.

No que diz respeito ao controle concentrado de constitucionalidade (revisão judicial abstrata), reiteradas decisões do Supremo Tribunal Federal (v.g., ADls no 2097, $520,2118,763)$ têm entendido que ocorre o prejuízo por perda superveniente de objeto (a despeito da norma alegadamente inconstitucional vier, ou não, a produzir efeitos concretos) quando, durante a tramitação do processo, a referida norma for revogada 
ou ocorrer alteração posterior no texto constitucional, que convalide a situação antes incompatível com a Constituição Federal.

Seriam tais situações simples obras do acaso ou a consequência de uma postura estratégica dos julgadores frente a litígios cujo julgamento imporia à Corte custos políticos desnecessários? Um significativo conjunto de processos foi julgado prejudicado por perda superveniente do objeto (13,4\% do total)65, num recorrente comportamento dos Ministros do Supremo Tribunal Federal, os quais, por seletividade, quedam inertes frente à questionada inconstitucionalidade dos atos normativos impugnados, por longos períodos de tempo, somente julgando os processos quando configurada a hipótese de perda de objeto, pela revogação futura do ato impugnado ou pela alteração superveniente do Texto Maior.

Ao contrário de assumir os custos de declarar expressamente sua opção pela autorrestrição ou de julgar a constitucionalidade do ato, condutas normalmente esperadas em relação ao exercício da jurisdição, os órgãos julgadores utilizam o tempo como seu aliado, retardando o julgamento até que seja verificada a alteração nas circunstâncias de fato que envolvem o litígio e, por consequência, seja prejudicado o julgamento por perda superveniente do objeto.

\subsection{Ilegitimidade ativa superveniente: os efeitos do tempo sobre os Requerentes}

Reafirmou o Plenário desta Corte que a perda superveniente da representação parlamentar no Congresso Nacional provoca a descaracterização da legitimidade ativa do Partido Político, mesmo que satisfeita, no momento do ajuizamento da ação, a exigência prevista no art. 103, VIII da Constituição Federal. Precedentes: Agravos nas ADIs no 2202, 2465, 2723, 2837 e 2346, todos de relatoria do eminente Ministro Celso de Mello.

Min. Ellen Gracie, ADI 2035 AgR, 2003 (Destaque nosso).

Em momento pretérito, foi dominante no Tribunal o entendimento de que a perda do mandato parlamentar, em momento posterior ao ajuizamento do procedimento de controle concentrado de constitucionalidade, provocaria a condição de ilegitimidade ativa superveniente da legenda partidária para instaurar a jurisdição constitucional sobre a questão submetida ao exame pelo STF.

65 GOMES NETO, José Mário Wanderley; LIMA, Flávia Danielle Santiago. Explorando "o maravilhoso mistério do tempo": as hipóteses de "perda de objeto" como evidências de virtudes passivas na suprema corte brasileira. In: 10 Encontro da Associação Brasileira de Ciência Política, 2016, Belo Horizonte. Anais do $\mathbf{1 0}^{\circ}$ Encontro Nacional da Associação Brasileira de Ciência Política. Rio de Janeiro: ABCP, 2016. 
Trata-se de uma situação semelhante à perda do objeto, pois também decorre dos efeitos do tempo sobre a condição de continuidade do processo de controle concentrado de constitucionalidade, servindo de argumento formal para a não apreciação da controvérsia constitucional pela corte: fatos supervenientes ao ajuizamento da ação afetariam a natureza do requerente, excluindo as características fundamentais necessárias a enquadrá-lo no rol de legitimados previsto no art.103 da Constituição Federal.

Em diversas situações não se constitui, da mesma forma, mera obra do acaso, pois a perda superveniente da legitimidade, ocorrida no decorrer da tramitação do processo, é produto justamente de um processo que, por seletividade da respectiva relatoria, passou longos períodos aguardando julgamento, utilizando-se do "maraviIhoso mistério do tempo" de Bickel, até que esta virtude passiva surgisse e justificasse a extinção do processo e o seu não julgamento pela corte.

\section{CONCLUSÕES: AUTORRESTRIÇÃO JUDICIAL COMO EXPRESSÃO DE COMPORTAMENTO ESTRATÉGICO DELIBERADO DO STF}

Vê-se que o direito importa no estudo do comportamento judicial autorrestrito, seja por visões específicas sobre o papel de um tribunal (material), seja porque as cortes atuam a partir de argumentos processuais (formal), oferecendo variáveis que se dedicam a explicar as razões da ação contida e/ou a maneira como os julgadores justificam e viabilizam sua estratégia de não julgar determinados conflitos.

Para tanto, o STF dispõe de um amplo espectro de argumentos para interagir no plano político, fundamentando seu diálogo expresso ou tácito com as instituições majoritárias. Argumentos estes que conjugam as tradições norte-americana e européia do exercício do controle, ou seja, além de um modelo que une o tribunal topo do controle difuso (EUA) à corte encarregada do controle concentrado (Europa), o STF ainda dispõe de uma dogmática que lhe permite transitar por esses argumentos e utilizá-los seletivamente, sem estabelecer a priori os contornos de sua atuação.

Neste sentido, ao invés de simplesmente apresentar argumentos para não apreciar as demandas (virtudes passivas) ou deferir a competência decisória exclusiva aos poderes majoritários, com a suposição de que sua atuação é correta, o desenho institucional de nossa revisão judicial espera que a corte decida a questão (non liquet) que lhe foi submetida, não se eximindo de apreciar a suposta lesão ou ameaça a dispositivos constitucionais. A redução do grau de intervenção e o respeito às instituições representativas denotam uma flagrante restrição institucional, seja no plano interpretativo, seja no plano comportamental.

Tal conduta afeta o modelo de diálogos institucionais, pois concretiza uma limitação no plano institucional, operada por uma um Tribunal que não se reconhece como a principal instância do debate político ou enfrenta situações em que não deseja 
arcar com os demasiados custos políticos de assumir "a última palavra" sobre os litígios constitucionais, cujo julgamento tenha consequências, v.g., para o equilíbrio democrático, para o regular funcionamento das instituições ou para o crescimento econômico.

Identificar como o STF usa esses argumentos é questão urgente para os pesquisadores. Tão ou mais importante que discutir o papel das cortes é compreender como elas atuam e se omitem, de sorte a fornecer critérios voltados às características específicas dos tribunais, a partir das previsões normativas constitucionais e legais e da interpretação doutrinária que oferece os contornos de sua atuação.

Partindo do fato que os tribunais interagem e dialogam com os outros poderes, como consequência de suas configurações institucionais, este artigo ofereceu um olhar sobre esta temática, com base numa tentativa de se aproximar de uma visão normativa da atuação do STF, a partir de sua práxis.

\section{REFERÊNCIAS}

ALVES, José Carlos Moreira. Força vinculante das decisões do Supremo. Declaração de constitucionalidade. Juizados Especiais. Valorização dos recursos processuais. Revista dos Tribunais, São Paulo, ano 5, n. 18, 1997.

AMARAL, Gustavo. Direito, escassez e escolha: critérios jurídicos para lidar com a escassez de recursos e as decisões trágicas. 2. ed. Rio de Janeiro: Lumen Juris, 2010.

BARCELLOS, Ana Paula de. Neoconstitucionalismo, direitos fundamentais e controle das políticas públicas. Disponível em <http://www.mundojurídico.adv.br/cgibin/upload/texto853.pdf.>. Acesso em 1 nov 2015.

BARKOW, R. More Supreme than court? The fall of the political question doctrine and the rise of judicial supremacy. Columbia Law Review, New York, v. 102, n. 2, mar. 2002.

BARROSO, Luís Roberto. O controle de constitucionalidade no direito brasileiro. São Paulo, Saraiva, 2008.

BICKEL, Alexander M. The least dangerous branch: the Supreme Court at the bar of politics. Indianapolis: Bobbs-Merrill, 1962.

BICKEL, Alexander M. The Supreme Court, 1960 Term - foreword: the passive virtues. Harvard Law Review, Cambridge, n. 75, p. 40-75, nov. 1961.

BRANDÃO, Rodrigo. O STF e o dogma do legislador negativo. Direito, Estado e Sociedade, Rio de Janeiro, n. 44, 2014.

BUCCI, Maria Paula Dallari. Notas para uma metodologia jurídica de análise de políticas públicas. In: FORTINI, Cristiana; ESTEVES, Julio César dos Santos; DIAS, Maria Tereza Fonseca (Org.). Políticas públicas: possibilidades e limites. Belo Horizonte: Fórum, 2008. 
CARVALHO, Ernani. Dimensão política do acesso à justiça: aspectos da revisão judicial. In: GOMES NETO, José Mário Wanderley (Org.). Dimensões do Acesso à Justiça. Salvador, Editora PODIVM, 2008.

CHOPER, Jesse H. The political question doctrine: suggested criteria. Duke Law Journal, Durham, v. 54, p. 1457-1523, 2005.

CINTRA, Antonio Carlos de Araújo; GRINOVER, Ada Pellegrini; DINAMARCO, Cândido Rangel. Teoria geral do processo. São Paulo, Malheiros, 2016.

DAHL, Robert A. Decision-making in a democracy: The Supreme Court as a national policy-maker. Journal of Public Law, London, v. 6, 1957.

DIAS, Gabriel Nogueira. "Legislador negativo" na obra de Hans Kelsen: origem, fundamento e limitações à luz da própria Reine Rechtslehre. Revista Brasileira de Estudos Constitucionais - RBEC, Belo Horizonte, ano 4, n. 15, jul./ago. 2010.

ELY, John Hart. Democracy and distrust: A theory of judicial review. Harvard University Press, 1980.

FALCÃO, Joaquim. O Supremo: compreenda o poder, as razões e as consequências das decisões da mais alta Corte do Judiciário no Brasil. Rio de Janeiro: Fundação Getúlio Vargas, 2015.

GOMES NETO, José Mário Wanderley et al. Litígios Esquecidos: Análise empírica dos processos de controle concentrado de constitucionalidade aguardando julgamento. Revista de Estudos Empíricos em Direito, v. 4, n. 2, p. 75-86, 2017.

GOMES NETO, José Mário Wanderley Gomes; LIMA, Flávia Danielle Santiago. Poder de agenda e estratégia no STF: uma análise a partir da decisão liminar nos mandados de segurança n 34.070 e no 34.071. In: MARTINS, Argemiro Cardoso Moreira et al. (Orgs.). Constituição e Democracia II. Florianópolis, CONPEDI, 2016.

GOMES NETO, José Mário Wanderley; LIMA, Flávia Danielle Santiago. Explorando "o maravilhoso mistério do tempo": as hipóteses de "perda de objeto" como evidências de virtudes passivas na suprema corte brasileira. In: 10 Encontro da Associação Brasileira de Ciência Política, 2016, Belo Horizonte. Anais do $\mathbf{1 0}^{\circ}$ Encontro Nacional da Associação Brasileira de Ciência Política. Rio de Janeiro: ABCP, 2016.

HALPERN, Stephen C.; LAMB, Charles M. Historical Perspectives. In: HALPERN, Stephen C.; LAMB, Charles M (ed.). Supreme Court activism and restraint. Lexington, Lexington Books, 1982.

HENKIN, Louis. Is there a "political question" doctrine? The Yale Law Journal, New Heaven, v. 85, n. 5, p. 597-625, apr. 1976.

HOLMES, Stephen; SUNSTEIN, Cass R. The cost of rights: why liberty depends on taxes. New York, London: W. W. Norton \& Company, 1999. 
KECK, Thomas M..The most activist Supreme Court in history: the road to modern judicial conservatism. Chicago: The University of Chicago Press, 2004.

LAMB, Charles M. Judicial Restraint on the Supreme Court. In: HALPERN, Stephen C.; LAMB, Charles $M(E d$.$) . Supreme Court activism and restraint. Lexington, LexingtonBooks, 1982$.

LIMA, Flávia Danielle Santiago. Jurisdição constitucional e política: ativismo e autocontenção no STF. Curitiba: Juruá, 2014.

LIMA, Flávia Danielle Santiago. Perdedores no Congresso Nacional e no STF? A judicialização das questões interna corporis do Legislativo. Revista Jurídica da Presidência, Brasília, v. 18, p. 307$330,2016$.

NOVAIS, Jorge Reis. Separação de poderes e limites da competência legislativa da Assembleia da República: simultaneamente um comentário ao Acórdão n. ${ }^{\circ}$ 1/97 do Tribunal Constitucional. Lisboa: Lex, 1997.

POSNER, Richard A. How judges think. Cambridge, Harvard University Press, 2010.

POSNER, Richard A. The rise and fall of judicial self-restraint. California Law Review, Berkeley, vol. 100, n. 3, p. 519-556, 2012.

SEIDMAN, Louis Michael. The secret life of the political question doctrine. John Marshall Law Review, v. 37, p. 441-480, 2004.

SILVA FILHO, Derly Barreto e. Controle dos atos parlamentares pelo poder judiciário. São Paulo: Malheiros Editores, 2003.

SOUZA JÚNIOR, Antônio Humberto. O Supremo Tribunal Federal e as questões políticas. Porto Alegre: Síntese, 2004.

SUNSTEIN, Cass R. Designing democracy: What constitutions do. Oxford University Press, 2001. TEIXEIRA, José Elares Marques. A doutrina das questões políticas no Supremo Tribunal Federal. Porto Alegre: Sergio Antonio Fabris Editor, 2005.

TUSHNET, Mark. Law and prudence in the law of justiciability: the transformation and disappearance of the political question doctrine. North Carolina Law Review, Chapel Hill, v. 80, p. 1203$1235,2002$.

WHITTINGTON, Keith E. Legislative sanctions and the strategic environment of judicial review. International Journal of Constitutional Law, v. 1, n. 3, p. 446-474, jul. 2003. 